\title{
INNOVATIVE MODEL OF INTEGRATED ENERGY MANAGEMENT IN COMPANIES
}

DOI: 10.12776/QIP.V19I1.384

\author{
MILAN MAJERNÍK, MARTIN BOSÁK, LENKA ŠTOFOVÁ, \\ PETRA SZARYSZOVÁ
}

Received 15 September 2014, Revised 10 December 2014, Accepted 20 April 2015

\begin{abstract}
Purpose: To propose and verify an innovative concept model of integrating standardized energy management system according to ISO 50001 management system of enterprises in the network of automobile suppliers.
\end{abstract}

Methodology/Approach: Based on an analysis of previous approaches to innovation and standardization of energy aspects of corporate management with an emphasis on principles and indicators of energy intensity in accordance with ISO 50001 there has been designed and by a case study verified model of integration of energy management in the specific company automobile production. Research output has been generalized and modified for repeated applications in this area.

Findings: Implementation of the integration model of energy management and energy performance indicators ISO 50001 demonstrate effectiveness of the management of energy and readiness for certification of energy management, increased energy efficiency and production system demonstrated the ability of continuous improvement of indicators.

Research limitation/implication: Due to the low-energy environmental awareness it is necessary to invest funds including also external consultants, mobilize human resources of various departments, software, hardware and so on. The barrier is the lack of practical experience to the management of enterprise energy efficiency within the purview of BAT technology and due to the limitations of natural resources. Progressive development concepts and strategies in industry put more and more emphasis on energy quality of a corporate production. As the output of activities in this area standard ISO 50001 - Energy Management System was published by the International Organization for Standardization for international accreditation and certification. The standard 
provides guidance for organizations in addressing challenges associated with strengthening criteria of energy intensity and permanent improving of efficiency in energy consumption and meeting requirements of third parties. The authors, based on previously conducted case studies abroad and their own research in this area, formalize benefits from implementation of a standardized Energy Management System in companies of the automotive industry and present an innovative model of its integration into the overall system management comprising a methodology for implementation, maintenance and certification in terms of enterprises in Slovakia.

Keywords: energy quality; energy management system; innovative model; criteria of energy intensity, certification system

\section{INTRODUCTION}

Energy management system generally provides worldwide several significant advantages for small and large companies in public and private sectors, in manufacturing and services, in all areas of economic activities as well. The international standard ISO 50001 provides a framework and guidance for industrial, commercial, institutional, governmental departments and organizations in order to manage energy aspects of production. Focusing on the wide applicability across national economic sectors it is estimated within research that this standard could influence up to $60 \%$ of world energy consumption (Colesca and Ciocoiu, 2013). Energy is a decisive subject for all organizational activities and it can be prohibitively expensive for businesses, regardless of the field of their activity. This knowledge can be transformed even so, that the use of energy, from the raw materials to the waste recycling will be taken in consideration within the Supply Chain of the company (Zgodavová, 2002).

In addition of economic costs in the company, energy consumption can also negatively affect the elements of the environmental and the social cost ratio in the context of resource depletion, leading to subsequent problems, such as climate changes. Development and introduction of the new technologies and sources of energy, particularly renewable energy resources may also take longer time. The companies are not able to control each price of energy, but with help of the government and global economics it is possible to improve the way how the energy is immediately managed. Higher energy consumption can be beneficial for the company by maximizing the use of its energy resources and activities from energy point of view, thereby reducing the energy costs and consumption. At the same time there is a reduction of the energy resources depletion and at once mitigating the adverse impact on global energy use, such as global warming (Nenadál, 2008; Mizla and Pudło, 2012). International Standard ISO 50001 is based on a management system model, which is previously followed and implemented by businesses worldwide. In the near future it may have a positive 
meaning for businesses of all types and it also supports long-term effort to improve energy technology.

\section{METHODOLOGY OF CASE STUDY}

Objectives of energy management can provide an organized platform for integrated energy management performance for businesses. These include in parts adjustments of production processes, improving quality and increasing the energy efficiency of the company systems.

The analysed company belongs to the automotive industry SK NACE 29320 Manufacturing of other parts and accessories for motor vehicles, monitors policy for energy management, specializing in electronic parts and components for the automotive industry. The company has also implemented a quality management system according to EN ISO 9001:2009 environmental management system according to EN ISO 14001:2005 and quality management system ISO/TS 16949:2005.

\subsection{Standardized energy management system}

Standardized system of energy management provides an international framework for industrial plants, businesses and organizations in management of energy, including all aspects of these processes and a model of energy efficiency, as shown in Figure 1.

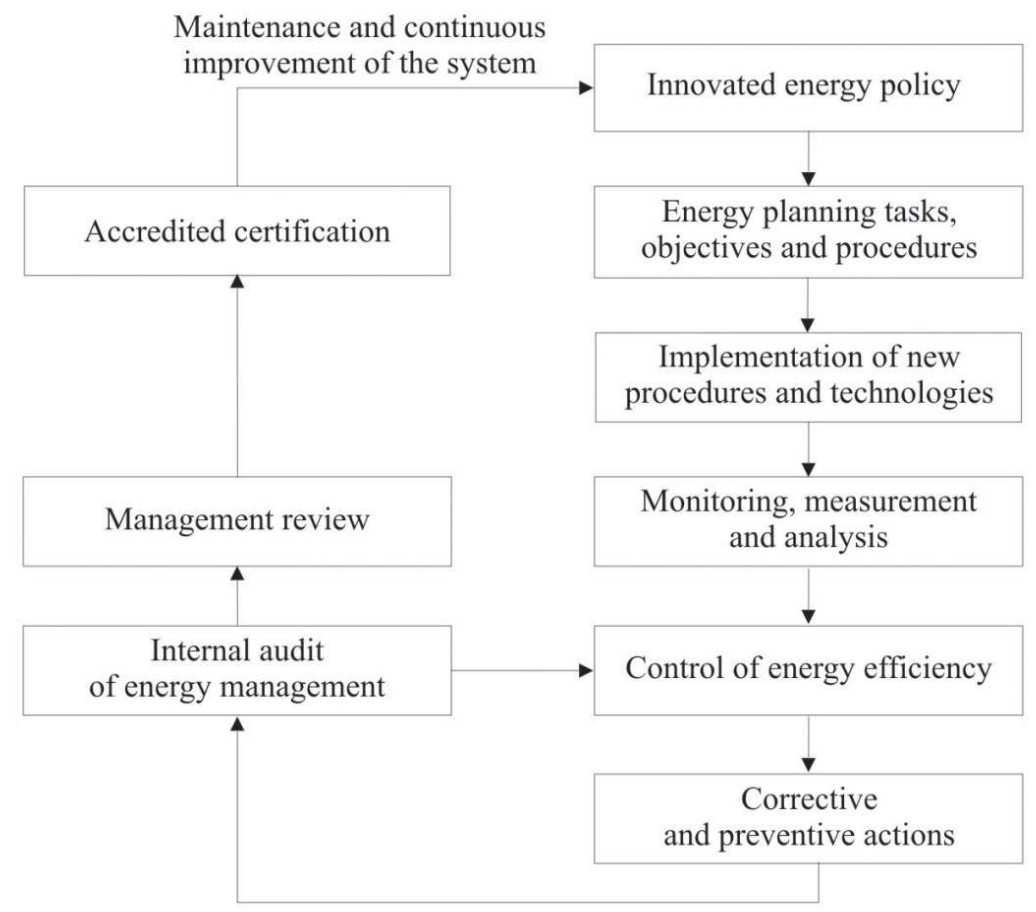




\section{Figure 1 - Innovated model of energy management according to international standard ISO 50001:2011}

Organizations and businesses are currently facing problems and challenges in integrating energy management and energy technologies in determining characteristics of energy consumption, mitigating technological barriers to improve quality, energy efficiency and provide the third-party certification in implementation of an energy management system according to ISO 50001:2011. International Standard ISO 50001 for energy management specifies requirements for the management system of consumption and use of energy, including a systematic approach for continuous improvement of energy quality, efficiency and performance. Integration of energy management in a company management system in accordance with international standard ISO 50001, including active key elements, can produce according to previous surveys an increase of effictiveness in energy efficiency in the range of $2 \%-5 \%$. System optimization can be achieved by increasing the average efficiency of about $20 \%-30 \%$ and provides verified model that helps companies to schedule and manage their energy consumption systematically (Meffert and McKane, 2011).

The international standard ISO 50001 provides to the companies of privet and public sector a management strategy which increases the energy efficiency, reduce costs and improves energy performance. The standard defines a general framework for companies, which integrates energy efficiency into their management processes and procedures. The standardized energy management system is based on common key elements of the management system standards, ensuring a high level of compatibility with other standards, such as quality management system according to STN EN ISO 9001:2009 and Environmental Management System according to STN EN ISO 14001:2005. Specifically, an energy management system according to ISO 50001:2011 can help businesses to implement the processes necessary to understand and use of energy, action plans, formulating targets and indicators in order to reduce the energy consumption, prioritizing and identification of opportunities for improving energy efficiency (Lambert, 2011).

Many developed countries but also developing countries currently provide practical binding regulations for their energy-intensive industries, followed by the inevitable implementing of energy management. Monitoring is used to control energy consumption of operations and businesses and long-term evaluations indicate either success or failure of energy management. The international Standard ISO 50001 ensures that the company respects the operational structure, system and procedures for the ongoing identification, prioritization, implementation and measuring the impact of energy saving projects (to ensure the persistence of energy benefits) (Fossa, 2012).

Examples of the energy management system usage according to ISO 50001:2011 are listed as follows (ISO 50001:2011): 
1) Comparison of annual energy use with targeted use.

2) Energy usage, which is a type of specific energy consumption, which can be used.

3) In some cases, a normalized energy consumption can be used when the normalization are factors representing the quantity of production, current seasonal fluctuations in temperature and time of service. Methods, such as a linear compensation or theoretical-methodological calculation may vary. This type of tool which creates an overview is useful in order to explain the change in the nature of energy performance indicators (EPI) resulting from factors besides the measures for improvement.

4) The company can decide which variables EPI will not be measured and based on that a plan of measurement is developed and realized. The results are included in the energy line for reliable interval of measurements.

5) Statistical tools can be used to measure the correlation of potential variables on the EPI indicators. Typical variables may include weather conditions, raw materials, or quality of energy sources.

6) The EPI indicators may be relevant for different functions and levels of the company. For the top management, the EPI indicators usually refer to the effects of costs and a support of strategic objectives.

Although businesses have implemented the energy management system in order to achieve and maintain a higher energy efficiency, they may face with obstacles and problems in the implementation of an energy management system according to ISO 50001:2011, including its integration and technologies, definitions of energy intensity and indicators, technological improvements in energy efficiency and system certification by a third party. The international standard ISO 50001 defines energy performance indicators (EPI) as a quantitative index of energy intensity, which is determined by the plant itself. The concept of EPI can be used to compare the performance of the company at different times. They should be chosen to facilitate performance monitoring, especially in the use of energy in the energy profile of that company (Mirchi, 2012).

\subsection{Implementation of energy management}

Within implementation of the international standard ISO 50001, we created a conceptual model of integrating the energy management for improving energy performance indicators in the business and fulfilling the requirements of the system certification. In the study, the proposed model is used for establishment of sustainable development of energy management in the company and for integration of internal and external technical resources to create better energy technologies. The purpose of this study was to understand limits of resources of this model and further details for future analysis. 


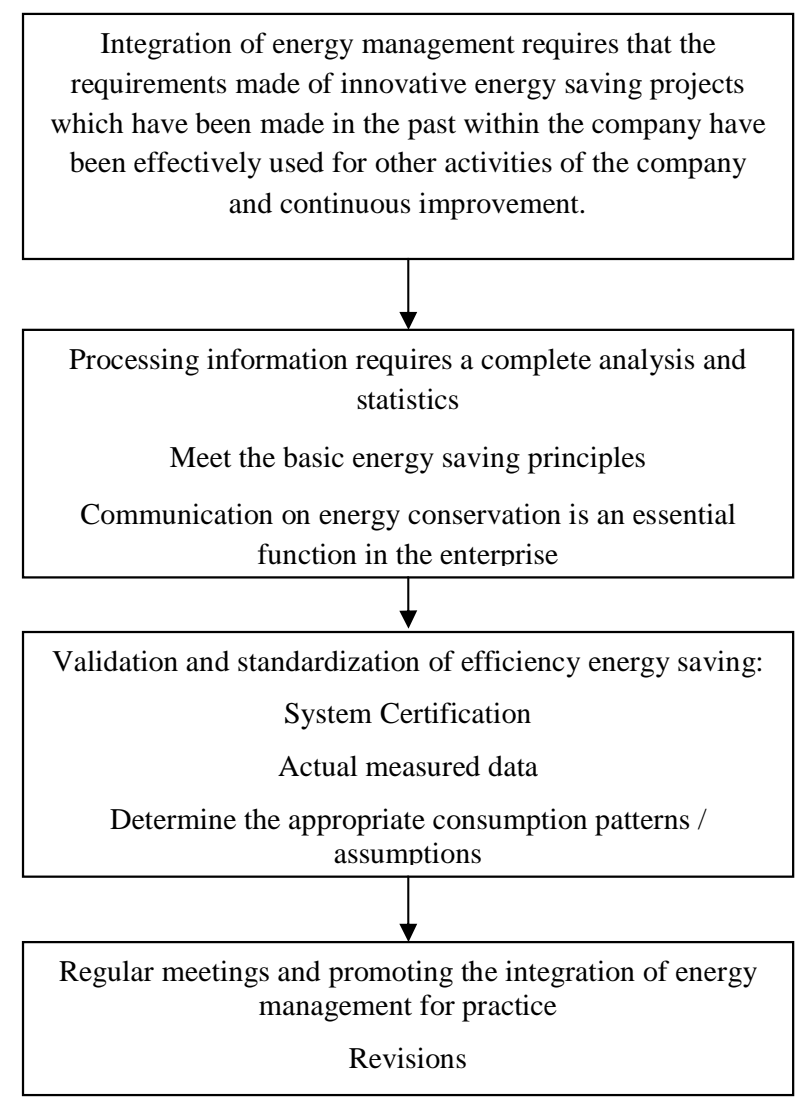

Figure 2 - Principles and procedures within evaluating a model integrating energy management

Source: Authors according to Padash, Nejadian and Khodaparast (2010)

The indicators of energy intensity including various performance indicators for air conditioning systems, lighting system and selected cable components were defined within our case study. These energy intensity indicators were identified and systemized. Among the most important variables there were indicators of overall annual energy company savings and the total energy consumption of the company, as the main objective of the study. The calculation was based on EPI in an energy management system according to the international standard ISO 50001. The indicator of energy intensity for the company had been set for energy economy reduction in the years 2012 to 2013 of $10 \%$. The integration model of energy management should be used to improve the qualitative indicators of energy performance, energy intensity, increase energy efficiency and to meet the overall requirements of an energy management system according to ISO 50001:2011. The principle of evaluation of energy International Standard ISO 50001 specifies requirements for the use and consumption, including measurement, documentation, reporting, design and public procurement procedures, processes and personnel which contribute in energy efficiency 
improvement. The proposed energy management system according to ISO 50001:2011 shall be applied to all variables affecting energy performance that can be monitored and influenced by businesses. Regarding energy, the international standard ISO 50001 does not prescribe specific performance criteria.

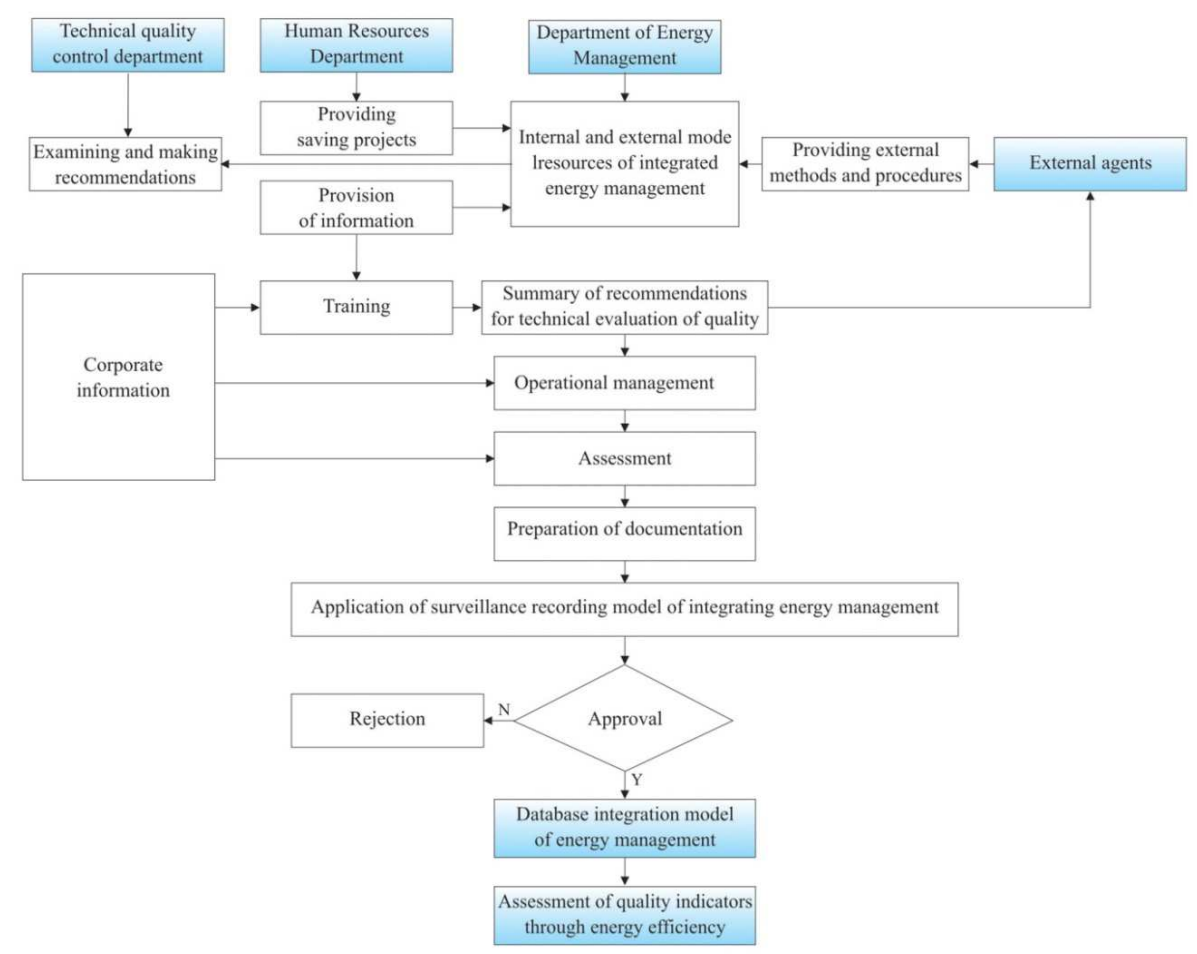

Figure 3 - Review of processes of energy integration management model

The model of integration and assessment of energy management in principle involves the collection and integration of energy-saving programmes of each department of the company. After examining the integration of energy management model there was created an integration database of energy management for the company. This database is available for all departments for evaluation and selection of standardized source of cases for further business activity. This helps the model to achieving synergies of indicators of maximum energy savings and increased energy economy for energy management, as shown on Figures 2 and 3.

\subsection{Formalization and application of benchmarks in energy intensity}

Requirements of an energy management system according to ISO 50001:2011 under the organization of energy consumption and related to operating instructions are still better structured so that the system ensures that energy standards and performance indicators are in a line with organizational 
requirements. Energy criteria must serve as a reference framework for quantitative comparison of energy intensity lines (McKane et al., 2009).

Output values within our research were obtained from the finance department of the company. Energy data for this study were obtained from the monthly accounts of the local power company. Energy intensity indicators relate to the quantified values of monitored indicators of energy consumption for businesses. Energy performance indicators are defined as the total energy efficiency of the company or a unit of energy output / production. Measuring energy consumption as output, was used as a whole.

\subsubsection{Creating a database of energy-efficient solutions}

To create a model of integration and assessment of energy management there have been used internal and external effective and feasible energy saving programmes. In addition, basic and priority solutions for saving energy (Table 1), are based to support the decision of various departments with reference to the selection of appropriate energy-saving programmes for adoption and gathering knowledge and experience about energy efficient technologies. Databases of energy-efficient solutions assist (also according to foreign resources in general) in the performance indicators of energy efficiency and provide the sustainable improvement of energy efficiency (MacDonald and Skaggs, 2012). Department of energy management in the company is responsible for supporting the implementation of innovative models of integrating energy management and energy saving solutions databases, operation and maintenance information system.

Table 1 - Types of energy use and energy-saving solution

\begin{tabular}{|c|c|c|c|c|c|}
\hline \multicolumn{6}{|c|}{ ENERGY MANAGEMENT } \\
\hline $\begin{array}{c}\text { ENERGY } \\
\text { CLASSIFICATION }\end{array}$ & $\begin{array}{l}\text { Air conditioning } \\
\text { systems }\end{array}$ & $\begin{array}{l}\text { Air compression } \\
\text { systems }\end{array}$ & $\begin{array}{l}\text { Electricity for } \\
\text { production }\end{array}$ & $\begin{array}{c}\text { Electricity for } \\
\text { normal operating } \\
\text { activities }\end{array}$ & $\begin{array}{c}\text { Electric energy for } \\
\text { other activities and } \\
\text { control }\end{array}$ \\
\hline \multirow[t]{7}{*}{$\begin{array}{l}\text { ENERGY SAVING } \\
\text { SOLUTIONS }\end{array}$} & \multirow[t]{4}{*}{$\begin{array}{l}\text { reducing of the air } \\
\text { conditioning load }\end{array}$} & $\begin{array}{l}\text { control inverter / } \\
\text { efficiency }\end{array}$ & \multirow[t]{4}{*}{$\begin{array}{l}\text { energy saving of } \\
\text { burning systems }\end{array}$} & energy saving systems & \multirow{2}{*}{$\begin{array}{l}\text { optimal demand } \\
\text { management / } \\
\text { intelligent control }\end{array}$} \\
\hline & & \multirow{4}{*}{$\begin{array}{l}\text { optimization / reduction } \\
\text { of energy consumption } \\
\text { pressure }\end{array}$} & & & \\
\hline & & & & \multirow{5}{*}{$\begin{array}{l}\text { use of altemative } \\
\text { energy }\end{array}$} & use of high-efficiency \\
\hline & & & & & $\begin{array}{l}\text { cogeneration of } \\
\text { electricity and heat }\end{array}$ \\
\hline & \multirow{2}{*}{$\begin{array}{l}\text { use of alternative } \\
\text { energy }\end{array}$} & & \multirow{2}{*}{$\begin{array}{l}\text { energy savings in } \\
\text { lighting systems }\end{array}$} & & \\
\hline & & \multirow[t]{2}{*}{ recycling of waste heat } & & & \\
\hline & $\begin{array}{l}\text { optimization of air } \\
\text { conditioning systems } \\
\text { and water cooling }\end{array}$ & & $\begin{array}{c}\text { energy savings in } \\
\text { production of cable } \\
\text { hamesses }\end{array}$ & & \\
\hline $\begin{array}{l}\text { PRODUCT SAVING } \\
\text { APPLICATIONS }\end{array}$ & $\begin{array}{l}\text { Hardware: temperature } \\
\text { controllers, frequency } \\
\text { converters, man } \\
\text { machine interface, AC } \\
\text { motors and actuators, } \\
\text { pressure sensors } \\
\text { Software: automatic } \\
\text { control systems, } \\
\text { programmable logic } \\
\text { system management } \\
\text { energy savings }\end{array}$ & 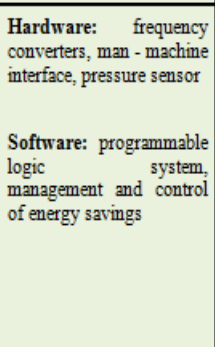 & $\begin{array}{l}\text { Hardware: frequency } \\
\text { inverters, servo drives } \\
\text { variables, man - } \\
\text { machine interface, } \\
\text { wireless receivers, } \\
\text { electronic ballast, } \\
\text { LED, wireless lighting } \\
\\
\text { Software: } \\
\text { programmable logic } \\
\text { system, management } \\
\text { and control of energy } \\
\text { savings }\end{array}$ & $\begin{array}{l}\text { Hardware: frequency } \\
\text { converters, AC motors } \\
\text { and drives, solar panels } \\
\text { Software: } \\
\text { Programmable logic } \\
\text { system, management } \\
\text { and control of energy } \\
\text { savings }\end{array}$ & $\begin{array}{l}\text { Digital metrics, } \\
\text { programmable logic } \\
\text { system, management } \\
\text { and control of energy } \\
\text { savings }\end{array}$ \\
\hline
\end{tabular}




\subsubsection{Certification of the energy management system according to ISO 50001:2011}

In this study, the innovative energy management model was used for implementation of an energy management system according to ISO 50001:2011, which allows various functional departments of the company to realize effective implementation and monitoring of corporate compliance plans of a required standard. External experts were hired to evaluate energy efficiency and to provide basic references for defining indicators of energy intensity.

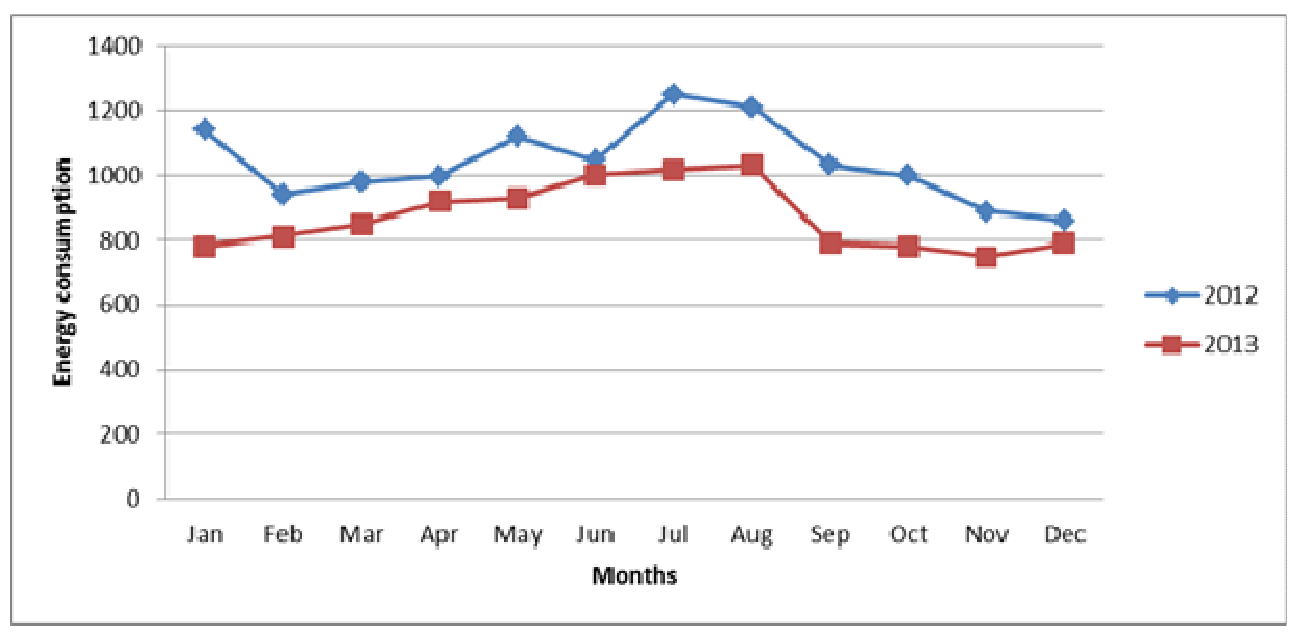

Figure 4 - Comparison of energy consumption before and after implementation of the energy management system model according to ISO 50001:2011 in 20122013

The results are showing that the energy consumption in the period between January and July 2013 (implementation phase) was lower than the same period in 2012 and continued to decline from July to November 2013. The slight increase in December, almost to the level of 2013, was caused by exceptional operating modes to fulfil the annual plan of orders. Based on that a new production line was build. At the same time by higher orders the production line and the robots were running at full speed by a complicated designs of products. Following the introduction of an innovative energy management model according to international standard ISO 50001:2011 the outcoming energy values are generally reduced once the model was implemented and realized.

\section{CONCLUSION}

In addition to the best-known and most frequently used quality standards ISO 9001, ISO 14001 environment, health and safety OHSAS 18001 a corporate energy management is currently also preferred in cooperation with the European strategic development documents (EUROPE 2020, HORIZON, 2020). 
The results of our research are showing that the integration of the energy management into functional company management system according to ISO 50001 will significantly improve its energy efficiency. The proposed model of integration and assessment is an effective tool for continuous improvement and sustainable business development. With this model implementation and evaluation of the companies energy management from the automotive industry the economy energy indicators were improved. Energy efficiency in the company increased in comparison with the base year 2012 (average annual decrease of $18.5 \%)$. By implementation of the energy management system according to ISO 50001:2011, energy efficiency indicators, energy intensity and energy efficiency indicators continuously decreased. This decrease was significant already in the phase of implementation and realization according to the monthly average of $2.6 \%$ compared to the period of the implementation with potential of further improvement in the future. The proposed model provides for the companies a tool and an effective method for development of sustainable use of energy. Although that its necessary to invest first in the business resources, including the external consultants, mobilization of competences and capabilities of human resources at various departments, software, hardware, certification, as well as other costs, return of an investment is based on the results more than obvious. These funds, along with long term and development trends for improving energy efficiency are therefore worth of further analysis, discussion and research. The proposed model can be modified according to specific requirements of companies, or due to limitations of natural resources in variety of industries and the level of company management system.

\section{REFERENCES}

Colesca, S.E. and Ciocoiu, C.N., 2013. An overview of the Romanian renewable energy sector. Renewable and Sustainable Energy Reviews, 24(August), pp.149158.

Fossa, J.A., 2012. ISO 50001 Energy Management System the Path, the Birth Story, the People Involved, Difficulties, Challenges, Relevant Discussions. [online] Available at: http://www.iso.org/sites/iso50001launch/assets/docs/03Alberto_Fossa-ISO\%2050001-the_path.pdf [Accessed 3 March 2012].

ISO 50001:2011. Energy Management System-Requirements with Guidance for Use, 2011. [online] Available at:

http://www.iso.org/iso/catalogue_detail?csnumber=51297 [Accessed 10 July 2011].

Lambert, G., 2011. ISO 50001 Pilot Program: US Companies Implement Standard with Government Support. [online] Available at: http://www.iso.org/iso/home/news_index/news_archive/news.htm?refid=Ref161 5 [Accessed 17 May 2011]. 
MacDonald, D. and Skaggs, J., 2012. ISO 50001 Energy Management: Continuous Improvement Driving Financial Results. [online] Available at: http://home.comcast.net/ aeeilliana/Presentations/ISO50001.pdf [Accessed 10 March 2012].

McKane, A. Desai, D., Matteini, M., Meffert, W., Williams, R. and Risser, R., 2009. Thinking Globally: How ISO 50001-Energy Management Can Make Industrial Energy Efficiency Standard Practice; Technical Report for Lawrence Berkeley National Laboratory: Berkeley, CA, USA, August 2009.

Meffert, B. and McKane, A., 2011. Development of an Energy Management Standard: ISO 50001. Available at:

http://texasiof.ces.utexas.edu/PDF/Documents_Presentations/Energy_Forums/IE TC2009/. Development\%20EnMS\%20IETC2009.pdf [Accessed 11 December 2011].

Mirchi, A., 2012. World energy balance outlook and OPEC production capacity: Implications for global oil security. Energies 5(8), pp. 2626-2651.

Mizla, M. and Pudło, P., 2012. Quality costs structure and company sensitivity to fluctuation of economy. E a M: Ekonomie a Management, 15(1), pp. 44-56.

Nenadál, J., 2008. Process performance measurement in manufacturing organizations, International Journal of Productivity and Performance Management, 57(6), pp. 460-467.

Padash, A., Nejadian, K. and Khodaparast, M., 2010. Sustainable development through matching requirements of energy management in HSE-MS. In: Proceedings of Renewable Energy 2010. Pacifico Yokohama, Japan, 2 July 2010.

Zgodavova, K., 2002. Factors of intensive product and service quality improvement. Ekonomicky casopis, 50(6), pp. 1005-1021.

\section{ABOUT THE AUTHORS}

Milan Majerník, prof. h. c., prof., Ing., PhD. - Professor, University of Economics in Bratislava, Faculty of Business Economics in Košice, Department of Management, Tajovského 13, 04130 Košice, e-mail: milan.majernik@euke.sk

Martin Bosák, prof. h. c., Ing., PhD. - Assistant Professor, University of Economics in Bratislava, Faculty of Business Economics in Košice, Department of Management, Tajovského 13, 04130 Košice, e-mail: martin.bosak@euke.sk

Lenka Štofová, Ing. - Internal PhD. Student, University of Economics in Bratislava, Faculty of Business Economics in Košice, Department of Management, Tajovského 13, 04130 Košice, e-mail: lenka.stofova@euke.sk

Petra Szaryszová, Ing., PhD. - Assistant Professor, University of Economics in Bratislava, Faculty of Business Economics in Košice, Department of Management, Tajovského 13, 04130 Košice, e-mail: petra.szaryszova@euke.sk 